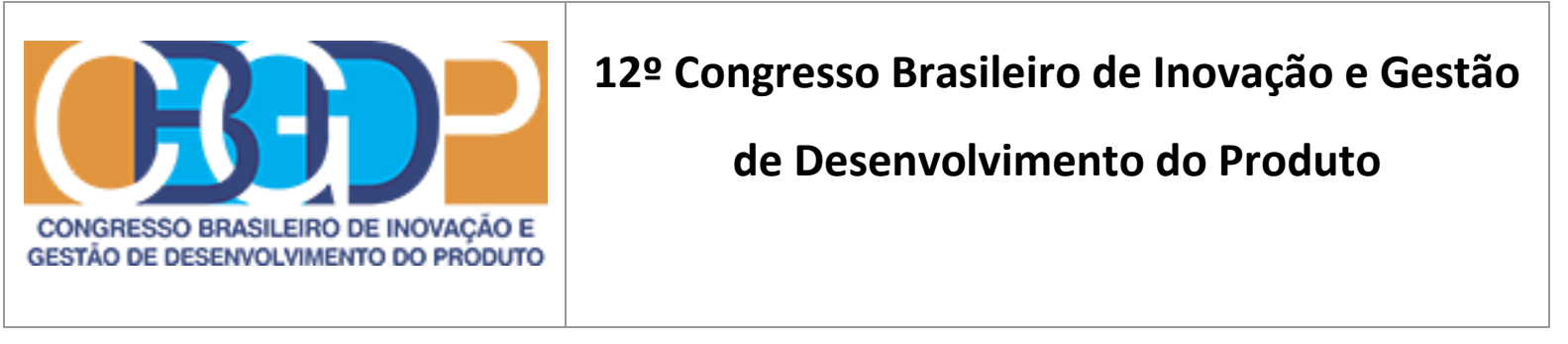

11 a 13 de setembro de 2019 - Universidade de Brasília UnB

\title{
DATABASE OF CASES OF PRODUCTS AND SOFTWARES DEVELOPMENT IN THE HEALTHCARE AREA
}

Isabela Cristina Simões Zacharias (isabela.zacharias@usp.br) - Departamento de Engenharia de Produção / Escola de Engenharia de São Carlos / Universidade de São Paulo

Thales Martins Ponciano (thalesmp@usp.br) - Departamento de Engenharia de Produção / Escola de Engenharia de São Carlos / Universidade de São Paulo

Carina Campese (carinacampese@yahoo.de) - Departamento de Engenharia de Produção / Escola de Engenharia de São Carlos / Universidade de São Paulo

Janaina Mascarenhas Hornos da Costa (janainacosta@usp.br) - Departamento de Engenharia de Produção / Escola de Engenharia de São Carlos / Universidade de São Paulo

\section{Abstract}

In the development of products it is important to know the best practices and techniques employed as a way to be able to adapt them to better results. The healthcare area benefits from such knowledge, since there are many challenges in identifying users and engaging them in the project in order to meet their needs. This study presents a database of cases of products and softwares development in the healthcare area. A systematic bibliographic review was carried out on the Scopus and Web of Science databases and articles that contained cases of product and/or software development in the healthcare area and presented details of the users' involvement throughout the development process were selected. The database is made up of 203 articles, 160 of which relate to software development, 26 are product development cases (hardware) and 18 describe product development with software. This database serves as a reference for researchers and practitioners who want to seek evidence of best practice and ways to engage users in the development of healthcare products/softwares.

Key-words: user involvement; participatory design; health; systematic review, bibliometric analysis. 


\section{INTRODUCTION}

Several norms are imposed in the medical area to avoid problems in the use of products and services and among them the need to involve users in the development process (MONEY et al., 2011; SHAH; ROBINSON, 2006). Money et al. (2011) have found that, even so, many product and service development processes still face difficulties. The authors emphasize the way to involve the user, which method to use and who are the users to be involved.

Shah and Robinson (2006) highlight the importance of involving the user in different stages of the product life cycle to capture different perspectives. Despite the large number of methods available, developers choose to use a limited range, according to an interview conducted by Shah and Robinson (2006). The authors identified that focus group methods and questionnaires are the most used when engaging users.

During a product/service development process, all user groups should be considered and participate in the engagement process (VON HIPPEL, 2005). However, in the medical field, identifying which users involve may be a problem. Money et al. (2011) they found that often only physicians are involved in the project. There are others that can be considered as users of healthcare products: general healthcare professionals, such as nurses and physiotherapists (MARTIN et al., 2010); patients with disabilities or with special needs (SHAH; ROBINSON; ALSHAWI, 2009); elderly patients (SHAH; ROBINSON; ALSHAWI, 2009); general patients (MARTIN et al., 2010); technician (PIETZSCH et al., 2009); and anyone who has contact with the product, such as product maintenance, cleaning, transportation and training (MARTIN et al., 2010), patients relatives and caregivers responsible for the surgery department (MARTIN et al., 2010), and researchers, students and trainees (SHAH; ROBINSON; ALSHAWI, 2009). Some user groups may be overlooked in development and this can lead to usability issues (CARRUTHERS; PHILIP, 2006).

Data from the studies of Shah, Robinson and Alshawi (2009) and Money (2011) on methods used and who are the users involved in product development were identified through interviews with medical product manufacturers and no literature research was done on a sample of able to discuss the state of the art. In order to explain a phenomenon and discuss a theory, Tranfield et. al. (2003) indicate the use of the systematic review. This study presents a literature database with information on product development processes (hardware) or software in the medical area where there were application of methods to involve the user. Data on quantity and incidence of 
methods used in user engagement, the types of users involved and the number of products and software were identified. The bibliometric analysis detected an increase number of publications on this topic, which countries are involved in the research, and also the journals.

\section{METHODOLOGY}

The combination of a systematic review and bibliometric analysis was used as methodology, proposed by Conforto, Amaral and Silva (2011). The objective of the SR is to generalize knowledge through theoretical synthesis in fields and subfields of research. This type of methodology has been frequent in the medical field in management research, probably because it can explain a phenomenon and at the same time ensure consistency in the analyzes of the theory (TRANFIELD; DENYER; SMART, 2003).

Conforto, Amaral \& Silva (2011) recommend a 3-step-roadmap to develop SR researches in the area of operations management, focusing on product development and project management. This research is organized into 3 phases: entry, processing and exit (Figure 1).

On the first phase, the research objective, sources (Scopus and Web of Science), search string and inclusion/exclusion criteria were defined.

On processing phase, the quantity of articles identified before and after the inclusion/exclusion criteria is presented. In total, 538 articles were retrieved in the search string, 63 were duplicates, so 475 articles were considered for the first filter in the processing phase. After reading the abstract of these articles, 332 were considered for the second filter and the entire article was read. On the last phase, bibliometric analysis from 203 papers were shown and discussed as a result. 


\begin{tabular}{c|c:c} 
& $\begin{array}{c}\text { Research } \\
\text { objective }\end{array}$ & Obtain a database for the development of medical products / services \\
\hline First phase - & Source & Web of Science and Scopus \\
Entry & Search string & $\begin{array}{l}\text { cent* design") AND TS=("product development" OR "product } \\
\text { design" OR "participatory design" OR "co-creation design") AND }\end{array}$ \\
& & TS=("health" OR "healthcare" OR "medical")
\end{tabular}

First filter: abstracts were read following the inclusion criteria;

Second filter: the entire paper was read following the inclusion criteria.

Second phase -

Processing

Third phase Exit
Total sample

(475) 1st filter 332 2nd filter 203

Database

\section{3 papers}

\section{Bibliometric analysis}

Database

Discussion

FIGURE 1 - Methodology process. Source: authors

\section{RESULTS AND DISCUSSION}

After the processing phase, 203 articles were cataloged (Appendix A). These studies present product (hardware) and/or software development in the medical field, all of them involve users throughout development.

\subsection{PRODUCT AND SOFTWARE}


Among the 203 papers, there is a great focus for the development of software (160 papers, ID 45 - 203). Programs are developed in 102 articles (ID 45 - 145); mobile application in 47 (ID 146 - 192); and websites in 11 papers (ID 193 - 203).

The product development corresponds to approximately $12 \%$ of the analyzed articles (26 papers, ID 1 -26), while the combination of software and product development in articles was the least identified. Only 18 articles (ID 27 - 44) products are developed related to a program or application.

\subsection{METHODS USED FOR USER INVOLVEMENT}

In the database were identified 24 different methods used to involve users in different stages of development, such as concept, design, testing and trials (SHAH; ROBINSON, 2006).

The most used method is "prototyping" (190 articles; 94\%). Only 10 of the software articles (159) do not use prototypes to test the generated concepts. However, in article ID 133 a usability test and a heuristic evaluation are applied, in this way, it is believed that a prototype of the developed software has been made, even if it is a low fidelity one. Otherwise, these tests could not be applied. Among product articles (with or without a combination with software - total of 44 ), only 3 of them do not use prototypes for testing. It should be noted that a minority of the articles develops more than one prototype throughout the development, being one of low fidelity (CHIOU et al., 2014) and at least one of high fidelity (RUDD; STERN; ISENSEE, 1996). This practice indicates that the interactivity of the development phases was performed (AITCHISON et al., 2009), a good development practice focused on the user.

The second most applied method is "interview" (149 articles, 73\%). Among these articles, only one (ID 92) makes exclusive use of this method, being a development for software. A good practice in health products / services development is the application of more than one method, having a combination of them, better extracting the usability aspects (SHAH; ROBINSON, 2006).

"Questionnaire" is the third most applied method (65 articles, 32\%). It is noted that the articles ID 6 (product development) and ID 39 (product development + software) only apply this method. This practice is also in agreement with the combination of methods by Shah and Robinson (2006).

Still with a significant percentage, the following methods are applied: observation $(\sim 29 \%)$ and focus group $(\sim 28 \%)$. The methods that obtained a lower index of application were: user cases 
(3 articles), contextual inquiry (3 articles) and storytelling ( 1 article). The latter 7 methods cited were applied for software development.

All the methods have greater application in the software area and none of them has a significant number of applications in the product developments in the articles analyzed. For example: 190 articles applying prototyping, only 24 are product development; of the 58 that apply focus group, only 5 are for product; of the 14 that apply personas, only 1 is for product.

Although some methods are quite common in the areas of product and software, they are still poorly applied in health care. For example, "heuristic assessment" is a method initially developed for software analysis (NIELSEN, 1993); however, it is poorly applied in healthcare technologies (5\% of articles with software or product development + software). The same happens with the "personas" method, common in information technology projects / softwares (GRUDIN; PRUITT, 2002; HJALMARSSON; GUSTAFSSON; CRONHOLM, 2015; RAMOS, 2013) and Web development (GARRETH, 2011), but only $8 \%$ of analyzed articles that develop software apply persona.

Figure 2 gives an overview of how many times the identified methods have been applied, and the relation of which methods are applied by which articles analyzed is in Appendix B. 

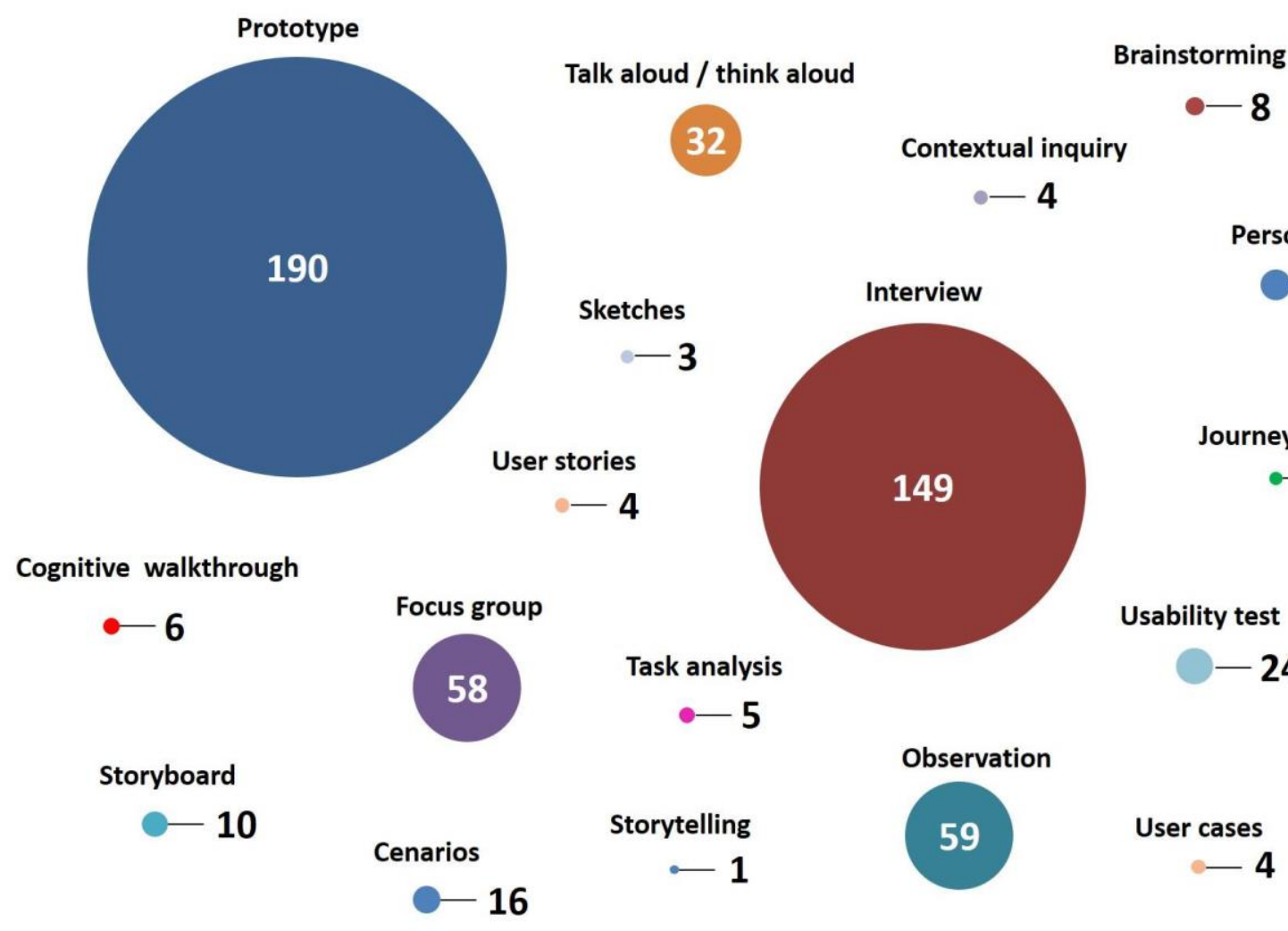
- 8 Contextual inquiry $-4$

Persona
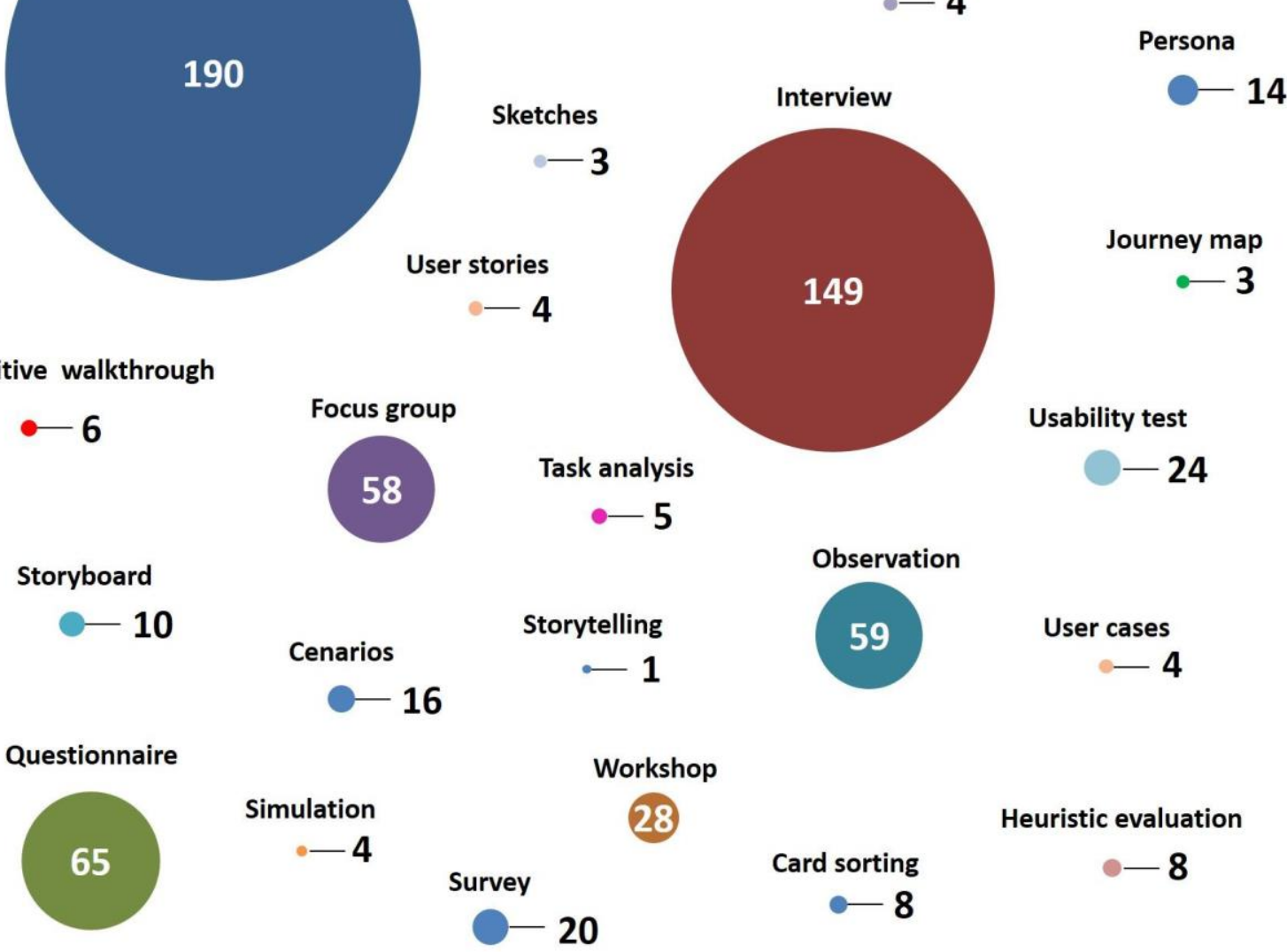

Workshop

28

\section{Observation}

User cases

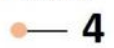

Usability test

\section{$-24$}

Journey map

- 3 
focused on patients but only involved health professionals. On the other hand, cases 53, 65, 86, 92 and 102 aimed to assist health professionals but only involved patients.

Among the analyzed articles, most focus on the involvement of patients and their families and/or caregivers, physicians and nurses (MARTIN et al., 2010; SHAH; ROBINSON; ALSHAWI, 2009). However, those database articles that develop products, none of them involves or mentions users who have indirect contact with the products, as responsible for maintenance, cleaning, transportation and training (MARTIN et al., 2010).

\subsection{Bibliometric analysis}

The case database is composed of articles published in journals (60\% - total of 122) and articles published in conferences (40\% - total of 81) (Figure 3). There is a greater number of publications concentrated in 7 journals, only one of which is not focused on healthcare, but rather has a scope of ergonomics and usability (Applied Ergonomics). These main journals are presented in Table 1.

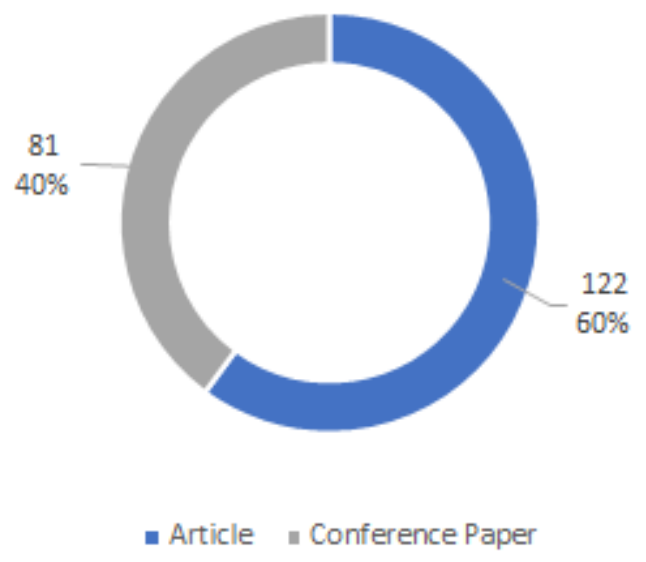

FIGURE 3 - Document type distribution. Source: authors

TABLE 1 - Main journals 


\begin{tabular}{|l|}
\hline \multicolumn{1}{|c|}{ Journals } \\
\hline Journal Of Biomedical Informatics \\
\hline Journal of Medical Internet Research \\
\hline International Journal of Medical Informatics \\
\hline Applied Ergonomics \\
\hline BMC Health Services Research \\
\hline BMC Medical Informatics And Decision Making \\
\hline Health Informatics Journal \\
\hline
\end{tabular}

Source: authors

The articles in the database come from 27 countries/territories (accounting carried out according to the country of the corresponding author of each article) (Figure 4). The highest number of cases was reported by authors from the USA (66), UK (25) and Canada (12). After them comes a great majority of European countries (Norway, Denmark, Sweden, the Netherlands and Germany). In Latin America, only 3 countries were identified (Brazil, Colombia and Argentina), Brazil being the largest number of cases (4).

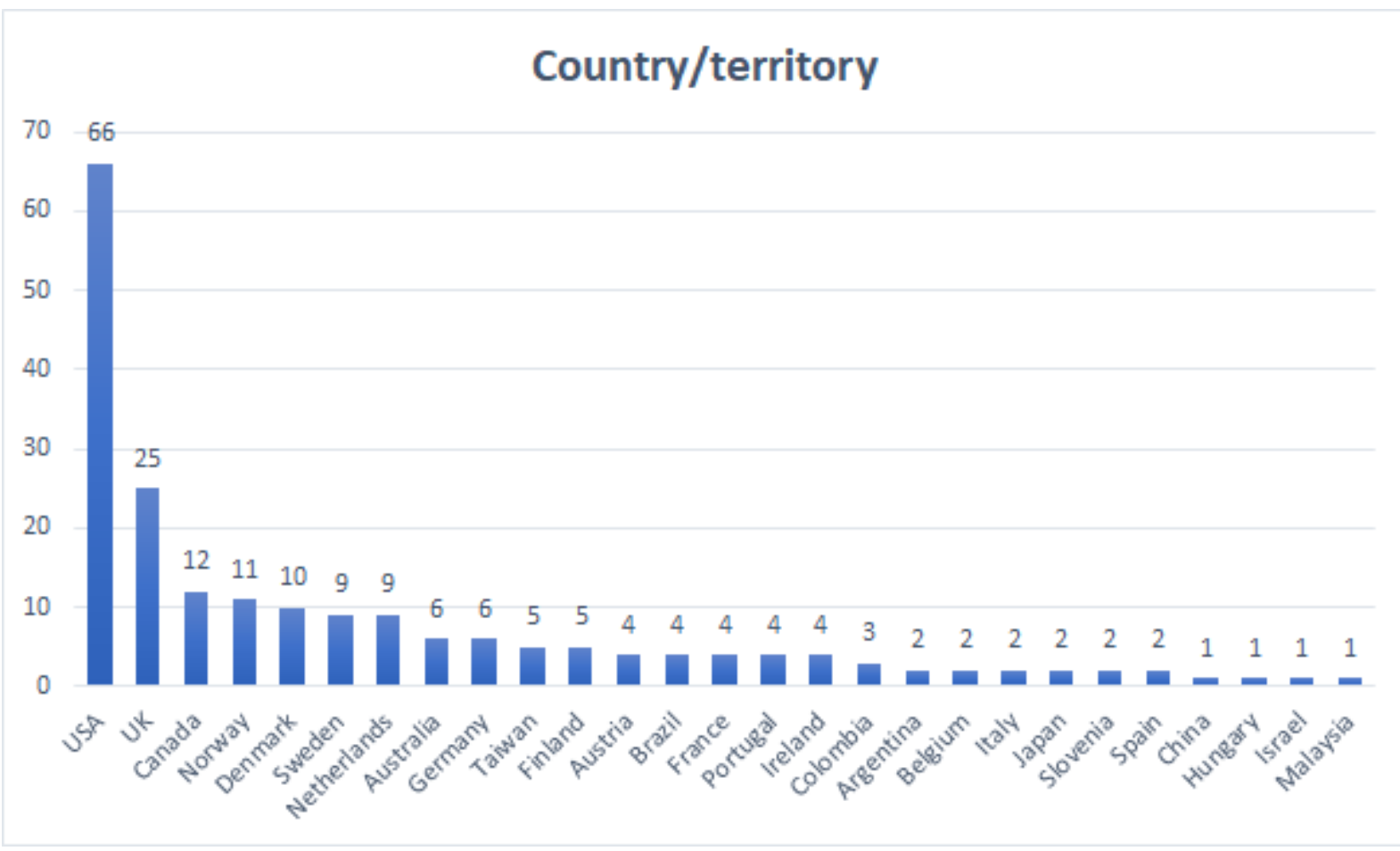

FIGURE 4 - Publication origin. Source: authors

The database comprises a period from 1986 to 2019, as can be seen in figure 5. Until 2004, there was a consistency of one article per year. Since then, there has been a growth in the publications of cases of products and/or software development in the healthcare area, such 
growth was accentuated from 2009. The peak of articles presented in the case database was in 2018 with 32 cases cataloged. The database has cases published in the year 2019, accounting for 15 cases so far.

The publication of the usability standards ISO 62366 in 2007 and ISO 60601-1-6 in 2010 may have influenced the increase of user involvement in the development of healthcare products and/or software. These standards guide that development must be done with the active participation of users. They have an international application, but they were published in the USA, which may be related to the large number of published cases in the country.

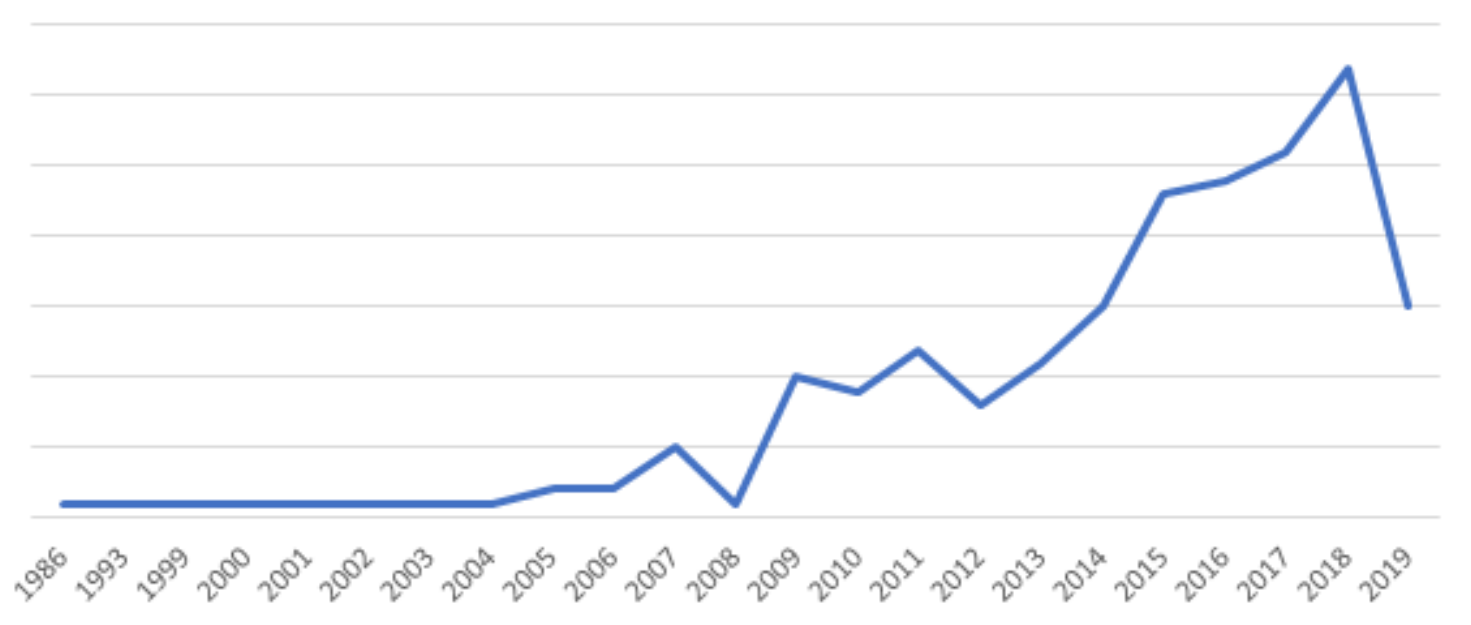

FIGURE 5 - Year of publication of the database articles. Source: authors

\section{CONCLUSION}

The database presents 203 cases of development of health products and softwares that have involved users throughout development, 160 articles developed software (software, websites and mobile applications), 26 developed products (hardware) and 18 developed products combination and software. Health product development faces the difficulty of managing the needs of different types of users, but despite this, most articles involve more than one type of user in their development cases.

All the cases from our database describe the user involvement through methods. In total 24 methods were applied as a form of user involvement, in which the use of prototypes for the 
development of products and softwares in the health area is highlighted. Interviews and questionnaires are also very applied.

Our database presents an extensive review period, articles from several countries and serves as a reference for developers and researchers wishing to rely on cases described in the healthcare product development literature.

\section{ACKNOWLEDGMENT}

This study was supported by Higher Education Personnel Improvement Coordination (Capes). The opinions, hypotheses, conclusions or recommendations expressed in this paper are of responsibility of the authors and do not necessarily reflect the views of Capes.

\section{REFERENCES}

AITCHISON, G. . et al. A Review of the Design Process for Implantable Orthopedic Medical Devices. The Open Biomedical Engineering Journal, v. 3, n. 1, p. 21-27, 2009.

CARRUTHERS, I.; PHILIP, P. Safety First: A report for patients, clinicians and healthcare managersDepartment of Health. [s.l: s.n.]. Disponível em: <http://webarchive.nationalarchives.gov.uk/20130107105354/http://www.dh.gov.uk/prod_consum _dh/groups/dh_digitalassets/@dh/@en/documents/digitalasset/dh_064159.pdf>.

CHIOU, E. et al. Contextual Design: Designing a device for motivated medication management. Ergonomics in Design: The Quarterly of Human Factors Applications, v. 22, n. 1, p. 8-15, 2014.

CONFORTO, E. C.; AMARAL, D. C.; SILVA, S. L. DA. Roteiro para revisão bibliográfica sistemática: aplicação no desenvolvimento de produtos e gerenciamento de projetos. $\mathbf{8}^{\circ}$ Congresso Brasileiro de Gestão de Desenvolvimento de Produto - CBGDP 2011, v. 8, n. 12, 13 E 14 DE SETEMBRO DE 2011, p. 1-12, 2011.

GARRETH, J. J. The Elements of User Experience: User-Centered Design for the Web and Beyond. Second Edi ed. Berkeley.

GRUDIN, J.; PRUITT, J. Personas. Participatory Design and Product Development: An Infrastructure for Engagement. (T.Binder, J.Gregory, I.Wagner, Eds.) PDC 02 Proceedings of the Participatory Design Conference. Anais...Malmo, Sweden: 2002

HJALMARSSON, A.; GUSTAFSSON, E.; CRONHOLM, S. Exploring the Use of Personas in User-Centered Design of Web-based e-services. iConference 2015 Proceedings. 2015

MARTIN, J. L. et al. Design for patient safety. User testing in the development of medical devices. London National Patient Safety Agency, 2010.

MONEY, A. G. et al. The role of the user within the medical device design and development process: medical device manufacturers' perspectives. BMC Medical Informatics and Decision Making, v. 11, n. 1, p. 15, 2011.

NIELSEN, J. Usability Engineering. Elsevier, 1993. 
PIETZSCH, J. B. et al. Stage-Gate Process for the Development of Medical Devices. Journal of Medical Devices, v. 3, n. 2, p. 021004, 2009.

RAMOS, E. DE S. Elaboração de uma Persona para o profissional de Análise de Requisitos que pratica UX/UCD/IHC baseado em dados estatísticos provenientes de pesquisas no contexto brasileiro. Encontro Anual de Tecnologia da Informação e Semana Acadêmica de Tecnologia da Informação. Frederico Westphalen: 2013.2 Disponível em: <http://www.eati.info/eati/2013/assets/anais/artigo288.pdf>

RUDD, J.; STERN, K.; ISENSEE, S. Low vs. high-fidelity prototyping debate. interactions, v. 3, n. 1, p. 7685, 1996.

SHAH, S. G. S.; ROBINSON, I. User involvement in healthcare technology development and assessment: Structured literature review. International Journal of Health Care Quality Assurance, v. 19, n. 6, p. 500-515, 2006.

SHAH, S. G. S.; ROBINSON, I.; ALSHAWI, S. Developing medical device technologies from users' perspectives: A theoretical framework for involving users in the development process. International Journal of Technology Assessment in Health Care, v. 25, n. 4, p. 514-521, 2009.

STACCINI, P. et al. Modelling health care processes for eliciting user requirements: A way to link a quality paradigm and clinical information system. International Journal of Medical Informatics, v. 64, n. 2-3, p. 129-142, 2001.

TRANFIELD, D.; DENYER, D.; SMART, P. Towards a Methodology for Developing Evidence-Informed Management Knowledge by Means of Systematic Review. British Journal of Management, v. 14, n. 3, p. 207-222, 2003.

VON HIPPEL, E. Democratizing innovation: The evolving phenomenon of user innovation. Journal fur Betriebswirtschaft, v. 55, n. 1, p. 63-78, 2005. 


\section{APPENDIX A}

ID

AHRENS, M.; HEHENBERGER, P. Empathic-Design Assisted By the Kano Method - a Human-Centered Design Method for Medical Devices Considering Patients. In DS 80-9 20th International

1 Conference on Engineering Design (ICED 15) Vol 9: User-Centred Design, Design of Socio-Technical system. Milan, Italy: 2015

2 BRUTON, A. et al. The Design and Development of a New Light-Weight Portable Oxygen System. Journal of Medical Devices, v. 6, n. 3, p. $031007,2012$.

3 CAIRNS, N. et al. Rethinking the foam cosmesis for people with lower limb absence. Prosthetics and Orthotics International, v. 42, n. 2, p. 223-227, 2017.

4 CRESPIN, O. M. et al. Feasibility of adapting the fundamentals of laparoscopic surgery trainer box to endoscopic skills training tool. Surgical Endoscopy, v. 32, n. 6, p. 2968-2983, 2018.

5 DONG, H.; VANNS, N. Designing an innovative pill dispenser: An undergraduate level case study of inclusive design. Design Journal, v. 12, n. 1, p. $95-116,2009$.

GREEN, S. Westfocus designplus: Learnings from a major cross-disciplinary design, industry and academic network. DS 43: Proceedings of E and PDE 2007, the 9th International Conference on Engineering and Product Design Education.University of Northumbria, Newcastle, UK: 2007 Disponível em: <http://www.scopus.com/inward/record.url?eid=2-s2.0-

6 84859258601\&partnerID=40\&md5=91af36c0b10e32897886e6864e2fde94>

7 HAGEDORN, T. J.; KRISHNAMURTY, S.; GROSSE, I. R. An information model to support user-centered design of medical devices. Journal of Biomedical Informatics, v. 62, p. 181-194, 2016.

8 HAN, F.; SHIN, K.; CHOW, D. User-centred design approach for hydrotherapy wetsuit. International Journal of Fashion Design, Technology and Education, v. 9, n. 1, p. 16-22, 2016.

9 HANSON, L. et al. Digital Human Modeling in Health Care Industry. (V.G. Duffy, Ed.)International Conference on Digital Human Modeling. Berlin Heidelberg: Springer-Verlag, 2009

10 HARIH, G.; ČRETNIK, A. Interdisciplinary Approach to Tool-Handle Design Based on Medical Imaging. BioMed Research International, v. 2013 , p. 1-8, 2013.

JUDGE, S.; NASR, N.; HAWLEY, M. A User-Centred Approach Exploring the Potential of a Novel EMG Switch for Control of Assistive Technology. Studies in Health Technology and

11 Informatics, v. 242, p. 381-384, 2017.

KARLSSON, I. C. M. et al. Use-centred design of medical and healthcare technology: a pilot study of field tests as a development tool. International Journal of Biomedical Engineering and 12 Technology, v. 5, n. 1, p. 11, 2011.

13 LANGELL, A. et al. Thermal Coagulation Device for Treating Cervical Dysplasia. Surgical Innovation, v. 26, n. 2, p. 149-152, 2019.

14 LIEN, C.; LIU, P. Systematic Innovation by User-centered Design : Case Study in Ampoule Opener Design. International Journal of Systematic Innovation, v. 5, n. 2, p. 45-52, 2018. LORENZINI, G. C.; OLSSON, A.; LARSSON, A. User Involvement in Pharmaceutical Packaging Design - a Case Study. Ds87-8 Proceedings of the 21St International Conference on Engineering

15 Design (Iced 17), Vol 8: Human Behaviour in Design. VANCOUVER, CANADA: 2017

MERLO, C. et al. Proposal of a user-centred approach for CPS design: pillbox case study. Proceedings of 2nd IFAC Conference on Cyber-Physical Human-Systems. Anais...Elsevier B.V.,

16 2019Disponível em: <https://doi.org/10.1016/j.ifacol.2019.01.065>

MORRIS, K.; PARK, J.; SARKAR, A. Development of a Nursing Sports Bra for Physically Active Breastfeeding Women Through User-Centered Design. Clothing and Textiles Research Journal,

17 v. 35, n. 4, p. 290-306, 2017.

18 NÄGELE, L. V.; RYÖPPY, M.; WILDE, D. PDFi : Participatory Design Fiction with Vulnerable Users. Proceedings of the 10th Nordic Conference on Human-Computer Interaction.2018

19 NAIK, A. D. et al. User-centered design of discharge warnings tool for colorectal surgery patients. Journal of the American Medical Informatics Association, v. 24, n. 5, p. 975-980, 2017.

20 PAZART, L. et al. Consideration of the Human Factor in the Design and Development of a New Medical Device: Example of a Device to Assist Manual Ventilation. BIODEVICES.2017

POWER, E. J.; LEAPER, D. J.; HARRIS, J. M. Designing functional medical products for children with cancer. International Journal of Fashion Design, Technology and Education, v. 10, $n$. 3 , $p$.

21 381-386, 2017.

22 REISER, S. et al. Making Together: An Interdisciplinary, Inter-institutional Assistive-Technology Project. IEEE computer graphics and applications, v. 37 , n. 5, p. 9-14, 2017.

ROBINSON, L. et al. Keeping in Touch Everyday (KITE) project: Developing assistive technologies with people with dementia and their carers to promote independence. International

23 Psychogeriatrics, v. 21, n. 3, p. 494-502, 2009.

24

TSAI, C. C. et al. Usability and feasibility of PmEB: A mobile phone application for monitoring real time caloric balance. Mobile Networks and Applications, v. $12, \mathrm{n} .2-3$, p. $173-184,2007$.

TSVYATKOVA, D.; STORNI, C. Adapting design probes to explore health management practices in pediatric type 1 diabetes. Proceedings of the 2014 conference on Interaction design and 25 children. 2014

26 YIN, S. et al. Functional Redesign of the Hospital Trolley-Bed Tray Table. Ergonomics in Design, v. 24, n. 4, p. 20-26, 2016. 
27 AMIRIBESHELI, M.; BOUCHACHIA, H. A tailored smart home for dementia care. Journal of Ambient Intelligence and Humanized Computing, v. 9, n. 6, p. 1755-1782, 2018.

28 BATSIS, J. A. et al. Usability evaluation for the Amulet Wearable Device in rural older adults with obesity. Gerontechnology, v. 17, n. 3, p. 151-159, 2018.

29 BEECO, R. F. W. et al. Creation of User-Centered Reports for Patients and Medical Professionals. Proceedings of the Human Factors and Ergonomics Society 54 th Annual Meeting. Anais...2010

30 BELARDO, S.; KARWAN, K. R. The development of a disaster management support system through prototyping. Information and Management, v. 10 , n. 2, p. $93-102,1986$.

BELDEN, T. et al. Developing an advanced "tool" for the clinician; using industrial design and interface design together to bring technology into the hand of the user. Sixth Annual IEEE Symposium on

31 Computer-Based Medical Systems Benefits.1993

32 BOYINGTON, A. R. et al. Development of a computer-based system for continence health promotion. Nursing Outlook, v. 52, n. 5, p. 241-247, 2004.

FABRICANT, R. Incorporating guidance and rewards into a handheld-device user experience. Proceedings of the 2005 conference on Designing for User eXperience. 2005. Disponivel em:

33 <http://dl.acm.org/citation.cfm?id=1138235.1138271>

GEORGIOU, T. et al. A blended user centred design study for wearable haptic gait rehabilitation following hemiparetic stroke. 2015 9th International Conference on Pervasive Computing Technologies for

34 Healthcare (PervasiveHealth). IEEE. Anais...2015

35 HALL, M. L.; LOBO, M. A. Design and development of the first exoskeletal garment to enhance arm mobility for children with movement impairments. Assistive Technology, v. 30, n. 5, p. 251-258, 2018.

MADSEN, M. et al. Challenges in Applying Standard Telemedicine Solutions in the Home of Type 2 Diabetics. Proceedings of the 8th International Conference on Pervasive Computing Technologies for

36 Healthcare. ICST (Institute for Computer Sciences, Social-Informatics and Telecommunications Engineerin. Anais...2014

MAIER, A. M. et al. Remember to remember: A feasibility study adapting wearable technology to the needs of people aged 65 and older with mild cognitive impairment (MCI) and Alzheimer's dementia.

Proceedings of International Conference on Engineering Design (ICED 2015) Publication. 2015 Disponivel em: <https://www.scopus.com/inward/record.uri?eid=2-s2.0-

37 84979784061\&partnerlD=40\&md5=df523ef92687f9cca36bf116689c972b>

38 MARQUIS-FAULKES, F. et al. Gathering the requirements for a fall monitor using drama and video with older people. Technology and Disability, v. 17, n. 4, p. 227-236, 2005.

NI, T.; KARLSON, A. K.; WIGDOR, D. AnatOnMe : Facilitating Doctor-Patient Communication Using a Projection-Based Handheld Device. Proceedings of the SIGCHI Conference on Human Factors in Computing 39 Systems.2011 Disponivel em: <http://dl.acm.org/citation.cfm?id=1979437>

40 PERUZZINI, M.; GERMANI, M. A Service-oriented Architecture for Ambient-assisted Living. 22nd ISPE Inc. International Conference on Concurrent Engineering. Anais...2015

PILLALAMARRI, S. S.; HUYETT, L. M.; ABDEL-MALEK, A. Novel Bluetooth-Enabled Tubeless Insulin Pump: A User Experience Design Approach for a Connected Digital Diabetes Management Platform. Journal of

41 Diabetes Science and Technology, v. 12, n. 6, p. 1132-1142, 2018.

WEIGHTMAN, A. P. H. et al. Engaging children in healthcare technology design: Developing rehabilitation technology for children with cerebral palsy. Journal of Engineering Design, v. 21, n. 5, p. 579-600,

422010.

43 WIGGERMANN, N. et al. Human-Centered Design Process for a Hospital Bed: Promoting Patient Safety and Ease of Use. Ergonomics in Design, v. 27, n. 2, p. 4-12, 2019.

44 XIAO, D. et al. A newly designed portable ergonomic laparoscopic skills Ergo-Lap simulator. Minimally Invasive Therapy and Allied Technologies, v. 22, n. 6, p. 337-345, 2013.

ID

\section{Software - Programs}

Reference

ABIB, J. C.; ANACLETO, J. C. Interaction Design Process for Healthcare Professionals: formalizing user's contexts observations. Proceedings of the 14th Brazilian Symposium on Human Factors in

45 Computing Systems. Anais...2015

BARANYI, R. et al. NutritionRush-A serious game to support people with the awareness of their nutrition intake. 2017 IEEE 5th International Conference on Serious Games and Applications for Health,

46 SeGAH 2017. Anais...2017

47 BELDEN, J. L. et al. Designing a medication timeline for patients and physicians. Journal of the American Medical Informatics Association : JAMIA, v. 26, n. 2, p. 95-105, 2018.

BJERKAN, J.; HEDLUND, M.; HELLESO, R. Patients' contribution to the development of a web-based plan for integrated care-A participatory design study. Informatics for Health and Social Care, v. 40, n. 2,

48 p. 167-184, 2015

49 BOEHMER, K. R. et al. Meaningful conversations in living with and treating chronic conditions: Development of the ICAN discussion aid. BMC Health Services Research, v. 16, n. 1, p. 1-9, 2016.

50 B $\varnothing$ R SSUND, E. et al. A stress management app intervention for cancer survivors: Design, development, and usability testing. Journal of Medical Internet Research, v. 20, n. 9, p. 1-16, 2018.

51 BØRSTING, J.; CULÉN, A. L.; EIKE, M. C. Design of a reference handling system for clinical DNA sequencing analysis, 2015.

52 BOSSEN, C. Accounting and co-constructing: The development of a standard for electronic health records. Computer Supported Cooperative Work, v. 20, n. 6, p. 473-495, 2011.

53 BRENNAN, P. F.; DOWNS, S.; CASPER, G. Project HealthDesign: Rethinking the power and potential of personal health records. Journal of Biomedical Informatics, v. 43, n. 5, p. S3-S5, 2010.

BROX, E.; KONSTANTINIDIS, S. T.; EVERTSEN, G. User-Centered Design of Serious Games for Older Adults Following 3 Years of Experience With Exergames for Seniors: A Study Design. JMIR Serious

54 Games, v. 5, n. 1, p. e2, 2017.

CARR, E. C.; BABIONE, J. N.; MARSHALL, D. Translating research into practice through user-centered design: An application for osteoarthritis healthcare planning. International Journal of Medical

55 Informatics, v. 104, n. April, p. 31-37, 2017.

56 CHIOU, E. et al. Contextual Design: Designing a device for motivated medication management. Ergonomics in Design: The Quarterly of Human Factors Applications, v. 22, n. 1, p. 8-15, 2014.

57 CUTTING, E. et al. User-centered design of multi-gene sequencing panel reports for clinicians. Journal of Biomedical Informatics, v. 63, p. 1-10, 2016.

DAHL, Y.; HANSSEN, G. K. "Do You See What I Hear?”: Designing for Collocated Patient-Practitioner Collaboration in Audiological Consultations. Human-Computer Interaction, v. 33, n. 5-6, p. 372-421,

582018.

DAS, A.; SVANAES, D. Human-centred methods in the design of an e-health solution for patients undergoing weight loss treatment. International Journal of Medical Informatics, v. 82, n. 11, $p$

59 1075-1091, 2013

DE CROON, R.; KLERKX, J.; DUVAL, E. Design and evaluation of an interactive proof-of-concept dashboard for general practitioners. Proceedings - 2015 IEEE International Conference on Healthcare

60 Informatics, ICHI 2015. Anais...2015

61 DEVOGE, J. M. et al. Collaborating With Physicians to Redesign a Sign-Out Tool. Ergonomics in Design, v. 17, n. 1, p. 20-28, 2009.

62 DIMEFF, L. A. et al. A novel engagement of suicidality in the emergency department: Virtual Collaborative Assessment and Management of Suicidality. General Hospital Psychiatry, n. April, 2018. 
DIRIN, M.; DIRIN, A.; LAINE, T. H. User-centered design of a context-aware nurse assistant (CANA) at Finnish elderly houses. Proceedings of the 9th International Conference on Ubiquitous Information

63 Management and Communication. Anais...2015

DUONG, T. A.; FAREL, R.; STAL-LE-CARDINAL, J. PSS for Healthcare Service Engineering, a User-Centered Approach Using Social Network. ICoRD'15-Research into Design Across Boundaries. Anais...New 64 Delhi: 2015Disponivel em: <http://link.springer.com/10.1007/978-81-322-2232-3>

FARINANGO, C. D. et al. Human-centered design of a personal health record system for metabolic syndrome management based on the ISO 9241-210:2010 standard. Journal of Multidisciplinary

65 Healthcare, v. 11, p. 21-37, 2018

FLOHR, L. et al. Clinician-Driven Design of VitalPAD-An Intelligent Monitoring and Communication Device to Improve Patient Safety in the Intensive Care Unit. IEEE Journal of Translational Engineering 66 in Health and Medicine, v. 6, n. March, p. 3000114, 2018.

GAO, T. et al. Participatory user centered design techniques for a large scale ad-hoc health information system. Proceedings of the 1st ACM SIGMOBILE international workshop on Systems and

67 networking support for healthcare and assisted living environments. 2007

GARCIA, J. J. . et al. Fine-tuning a context-aware system application by using user-centred design methods. Proc. of the IADIS Int. Conf. Interfaces and Human Computer Interaction 2010, IHCI, Proc. of the IADIS Int. Conf. Game and Entertainment Technologies 2010, Part of the MCCSIS 2010.2010 Disponivel em: <http://www.scopus.com/inward/record.url?eid=2-s2.0-

68 79955400128\&partnerID=40\&md5=99f791e2bb56e5ca3a3b6cc083744af7>

69 GELEIJNSE, G. et al. A personalized recipe advice system to promote healthful choices. IUI 2011: International Conference on Intelligent User Interfaces. Palo Alto, CA, USA: 2011

70 GONG, Y.; CHANDRA, A.; WANG, J. Toward an integrated health data display for aging in place. Studies in Health Technology and Informatics, v. 201, n. June, p. $233-240,2014$.

GRIM, K. et al. Development and usability testing of a web-based decision support for users and health professionals in psychiatric services. Psychiatric Rehabilitation Journal, v. 40, n. 3, p. 293-302,

712017.

HARTE, R. et al. Human-Centered Design Study: Enhancing the Usability of a Mobile Phone App in an Integrated Falls Risk Detection System for Use by Older Adult Users. JMIR mHealth and uHealth, v. 5,

72 n. 5, p. e71, 2017.

HARTSWOOD, M. et al. Being there and doing IT in the workplace: A case study of a co-development approach in healthcare. Proceedings of the CPSR/IFIP WG 9.1 participatory design conference.

73 Anais...2000

74 HOGARTH, M. et al. The Communication and Care Plan: A novel approach to patient-centered clinical information systems. Journal of Biomedical Informatics, v. $43, \mathrm{n}$. 5, p. S6-S8, 2010.

HOIZINGER, A.; SAMMER, P. HOFMANN-WELLENHOF, R. Computers Helping People with Special Needs. Lecture Notes in Computer Science. Anais...2006Disponivel em:

75 <http://link.springer.com/10.1007/978-3-642-31522-0>

HORSKY, J.; RAMELSON, H. Z. Development of a cognitive framework of patient record summary review in the formative phase of user-centered design. Journal of Biomedical Informatics, v. 64, p.

76 147-157, 2016

HØYBYE, M. T. et al. Virtual environments in cancer care: Pilot-testing a three-dimensional web-based platform as a tool for support in young cancer patients. Health Informatics Journal, $v$. $24, n$. $4, p$.

77 419-431, 2018

HUA, L.; GONG, Y. Identifying and addressing effectiveness in a user-centered design of voluntary medical incident reporting system. 2011 IEEE 13 th International Conference on e-Health Networking,

78 Applications and Services, HEALTHCOM 2011. Anais...IEEE, 2011

HWANG, A.; TRUONG, K.; MIHAILIDIS, A. Using participatory design to determine the needs of informal caregivers for smart home user interfaces. 20126 th International Conference on Pervasive

79 Computing Technologies for Healthcare (PervasiveHealth) and Workshops.IEEE, 2012

80 IZARD, J. et al. User-centered design of quality of life reports for clinical care of patients with prostate cancer. Surgery (United States), v. 155, n. 5, p. 789-796, 2014.

JOHNSEN, H. M. et al. Teaching clinical reasoning and decision-making skills to nursing students: Design, development, and usability evaluation of a serious game. International Journal of Medical

81 Informatics, v. 94, p. 39-48, 2016

82 KALLEN, M. A.; YANG, D. S.; HAAS, N. A technical solution to improving palliative and hospice care. Supportive Care in Cancer, v. 20, n. 1, p. 167-174, 2012.

KAMAL, N. et al. VivoSpace: Towards health behavior change using social gaming. Lecture Notes in Computer Science (including subseries Lecture Notes in Artificial Intelligence and Lecture Notes in

83 Bioinformatics). Anais...2011

84 KANG, H.; GONG, Y. Design of a user-centered voluntary reporting system for patient safety events. Studies in Health Technology and Informatics, v. 245, n. January, p. 733-737, 2017.

85 KATO, C. et al. Development of online counseling system and usability evaluation. Journal of Emerging Technologies in Web Intelligence, v. 3, n. 2, p. 146-153, 2011.

86 KILSDONK, E. et al. From an expert-driven paper guideline to a user-centred decision support system: A usability comparison study. Artificial Intelligence in Medicine, v. 59, n. 1, p. 5-13, 2013.

87 KLEMETS, J.; DE MOOR, K. Patient responsibility reallocation: A user-centered approach to support nurses' handling of nurse calls. Personal and Ubiquitous Computing, v. 19, n. 3, p. 601-621, 2015.

88 KLOMPMAKER, F. et al. Designing a telemedical system for cardiac exercise rehabilitation. Communications in Computer and Information Science, p. $111-122,2010$.

KUNJAN, K.; DOEBBELING, B.; TOSCOS, T. Dashboards to Support Operational Decision Making in Health Centers: A Case for Role-Specific Design. International Journal of Human-Computer Interaction,

89 v. 35, n. 9, p. 742-750, 2019

KUSHNIRUK, A.; NøHR, C. Participatory Design, User Involvement and Health IT Evaluation. In: AMMENWERTH, E.; RIGBY, M. (Eds.). . Evidence-Based Health Informatics Promoting Safety and Efficiency

90 Through Scientific Methods and Ethical Policy Edited. p. 389.

KWAHK, J.; SMITH-JACKSON, T. L.; WILLIGES, R. C. FROM USER-CENTEREDDESIGNTO SENIOR-CENTEREDDESIGN: DESIGNING INTERNET HEALTH INFORMATION PORTALS. PROCEEDINGS of

91 theHUMANFACTORS AND ERGONOMICS SOCIETY 45th ANNUAL MEETING. 2001

92 LEHOUX, P. et al. Clinicians as health technology designers: Two contrasting tales about user involvement in innovation development. Health Policy and Technology, v. 2, n. 3, p. 122-130, 2013.

LIN, C.-K. E.; WANG, T.-H.; YANG, J.-F. K. TOUCH Doctor - A Nutrition Control Service System Developed under Living Lab Methodology. International Journal of Automation and Smart Technology, v. 2 ,

93 n. 3, p. 253-263, 2012

94 LUNA, D. et al. Participatory design for drug-drug interaction alerts. Studies in Health Technology and Informatics, v. 210, n. May, p. 45-49, 2015.

LUNA, D. R. et al. User-centered design improves the usability of drug-drug interaction alerts: A validation study in the real scenario. Studies in Health Technology and Informatics, v. 245, n. January, p.

95 1085-1089, 2017.

MANN, D. M. et al. Rationale, design, and implementation protocol of an electronic health record integrated clinical prediction rule (iCPR) randomized trial in primary care. Implementation Science, $v$.

96 6, n. 1, p. 1-10, 2011.

MARSAC, M. L. et al. Systematic, theoretically grounded development and feasibility testing of an innovative, preventive web-based game for children exposed to acute trauma. Clinical Practice in

97 Pediatric Psychology, v. 3, n. 1, p. 12-24, 2015.

98 MARTIN-HAMMOND, A. M.; ABEGAZ, T.; GILBERT, J. E. Designing an over-the-counter consumer decision-making tool for older adults. Journal of Biomedical Informatics, v. 57, p. 113-123, 2015.

99 MARTIN, J. L.; BARNETT, J. Integrating the results of user research into medical device development: Insights from a case study. BMC Medical Informatics and Decision Making, v. 12, n. 1, p. 1-10, 2012.

100 MASSOUDI, B. L. et al. A web-based intervention to support increased physical activity among at-risk adults. Journal of Biomedical Informatics, v. 43, p. 541-545, 2010.

101 MATEO, K. F. et al. Development of a 5As-based technology-assisted weight management intervention for veterans in primary care. BMC Health Services Research, v. 18, n. 1, p. 1-14, 2018.

102 MOODY, L. et al. Design of a Handheld Computer Application for Clinical Critical Incident Reporting. Contemporary Ergonomics, p. 499-504, 2007.

103 MULVENNA, M. et al. Realistic expectations with brain computer interfaces. Journal of Assistive Technologies, v. 6, n. 4, p. 233-244, 2012.

NEBE, K.; GRÖTZBACH, L. Aligning user centered design activities with established software development practices. Proceedings of the 4th Nordic conference on Human-computer interaction: changing

104 roles.2006

105 NELSON, S. D. . et al. A case report of refining user requirements for a health information exchange dashboard. Applied Clinical Informatics, v. 7, n. 1, p. 22-32, 2016. 
NEUBECK, L. et al. Development of an integrated e-health tool for people with, or at high risk of, cardiovascular disease: The Consumer Navigation of Electronic Cardiovascular Tools (CONNECT) web

106 application. International Journal of Medical Informatics, v. 96, p. 24-37, 2016.

NOERGAARD, B. et al. Development of a Web-Based Health Care Intervention for Patients With Heart Disease: Lessons Learned From a Participatory Design Study. JMIR research protocols, v. 6, n. 5, p.

$1071-8,2017$.

NOTA, I. et al. Development of a web-based patient decision aid for initiating disease modifying anti-rheumatic drugs using user-centred design methods. BMC Medical Informatics and Decision

108 Making, v. 17, n. 1, p. 1-14, 2017

109 PARK, T. et al. Living Profiles: an example of user-centered design in developing a teen-oriented personal health record. Personal and Ubiquitous Computing, v. 19, n. 1, p. 69-77, 2015.

PELEG, M. et al. Using multi-perspective methodologies to study users' interactions with the prototype front end of a guideline-based decision support system for diabetic foot care. International

110 Journal of Medical Informatics, v. 78, n. 7, p. 482-493, 2009.

PIRES, M. R. G. M. et al. Sistema de Informação para a Gestão do Cuidado na Rede de Atenção Domiciliar (SI GESCAD): subsídio à coordenação e à continuidade assistencial no SUS. Ciência \& Saúde

111 Coletiva, v. 20, n. 6, p. 1805-1814, 2015.

PLAISANCE, A. et al. Development of a decision aid for cardiopulmonary resuscitation and invasive mechanical ventilation in the intensive care unit employing user-centered design and a wiki platform

112 for rapid prototyping. PLoS ONE, v. 13, n. 2, p. e0191844, 2018.

113 POUKE, M.; HÄKKILÄ, J. Elderly healthcare monitoring using an avatar-based 3D virtual environment. International Journal of Environmental Research and Public Health, v. 10, n. 12, p. 7283-7298, 2013. PRINCE, R. M. et al. User-Centered Design of a Web-Based Tool to Support Management of Chemotherapy-Related Toxicities in Cancer Patients. Journal of medical Internet research, v. 21, n. 3, p.

114 e9958, 2019.

PRINZ, A. et al. inSERT - An NFC-based self reporting questionnaire for patients with impaired fine motor skills. Proceedings - 3rd International Workshop on Near Field Communication, NFC 2011.

115 Anais...IEEE, 2011

116 PURI, S. K.; SAHAY, S.; LEWIS, J. Building participatory HIS networks: A case study from Kerala, India. Information and Organization, v. 19, n. 2, p. 63-83, 2009.

REIS, C. I. et al. Patient centered design: Challenges and lessons learned from working with health professionals and schizophrenic patients in e-therapy contexts. Communications in Computer and

117 Information Science, v. 221 CCIS, n. PART 3, p. 1-10, 2011.

REYNOLDS, L. M. et al. StreetWise: developing a serious game to support forensic mental health service users' preparation for discharge: a feasibility study. Journal of Psychiatric and Mental Health

118 Nursing, v. 24, n. 4, p. 185-193, 2017.

119 ROSS, S. E. et al. Two complementary personal medication management applications developed on a common platform: Case report. Journal of Medical Internet Research, v. 13, n. 3, p. 1-13, 2011.

120 SAVAZZI, F. et al. Engaged in learning neurorehabilitation: Development and validation of a serious game with user-centered design. Computers and Education, v. 125, n. June, p. 53-61, 2018.

SIRIARAYA, P. et al. Learnings and challenges in designing gamifications for mental healthcare: The case study of the readysetgoals application. 201810 th International Conference on Virtual Worlds

121 and Games for Serious Applications, VS-Games 2018 - Proceedings.IEEE, 2018

122 SLAGLE, J. M. et al. MyMediHealth - Designing a next generation system for child-centered medication management. Journal of Biomedical Informatics, v. 43 , n. 5, p. S27-S31, 2010.

123 SMARADOTTIR, B. et al. User-centred Design of the User Interface of a Collaborative Information System for Inter-municipal Dementia Team. HEALTHINF, p. 446-453, 2015.

SOLVOLL, T.; SCHOLL, J.; HARTVIGSEN, G. Physicians interrupted by mobile devices in hospitals: Understanding the interaction between devices, roles, and duties. Journal of Medical Internet Research,

124 v. 15, n. 3, p. 1-12, 2013.

SRINIVAS, P.; CORNET, V.; HOLDEN, R. Human Factors Analysis, Design, and Evaluation of Engage, a Consumer Health IT Application for Geriatric Heart Failure Self-Care. International Journal of Human-

125 Computer Interaction, v. 33, n. 4, p. 298-312, 2017.

126 SUTCLIFFE, A. et al. Developing visualization-based decision support tools for epidemiology. Information Visualization, v. 13, n. 1, p. 3-17, 2014

TANG, T. et al. Clinician user involvement in the real world: Designing an electronic tool to improve interprofessional communication and collaboration in a hospital setting. International Journal of

127 Medical Informatics, v. 110, p. 90-97, 2018.

TAYLOR, D. P. et al. User-centered development of a Web-based preschool vision screening tool. Annual Symposium Proceedings .2003 Disponivel em:

$128<$ <ttp://www.ncbi.nlm.nih.gov/pubmed/14728254>

TEIXEIRA, L.; FERREIRA, C.; SANTOS, B. S. User-centered requirements engineering in health information systems: A study in the hemophilia field. Computer Methods and Programs in Biomedicine, v.

129 106, n. 3, p. 160-174, 2012.

TENDEDEZ, H. et al. Scoping the Design Space for Data Supported Decision-Making Tools in Respiratory Care. Proceedings of the 12th EAI International Conference on Pervasive Computing Technologies 130 for Healthcare. 2018

TORRES, S. et al. The Development of a Communication Tool to Facilitate the Cancer Trial Recruitment Process and Increase Research Literacy among Underrepresented Populations. Journal of Cance

131 Education, v. 30, n. 4, p. 792-798, 2016.

TÓvÖLGYI, S. User involvement in the ergonomic development of a medical instrument: a longitudinal case study. International Journal of Occupational Safety and Ergonomics, v. 22, n. 2, p. 207-217,

1322016.

VAN DER WEEGEN, S. et al. The development of a mobile monitoring and feedback tool to stimulate physical activity of people with a chronic disease in primary care: A user-centered design. Journal of

133 Medical Internet Research, v. 15, n. 7, p. 1-13, 2013.

134 VENTURA, F. et al. Exploring the Person-Centeredness of an Innovative E-Supportive System Aimed at Person-Centered Care. CIN: Computers, Informatics, Nursing, v. 34 , n. 5, p. 231-239, 2016. VERHOEVEN, F.; VAN GEMERT-PIJNEN, J. Discount user-centered e-health design: a quick-but-not-dirty method. In Symposium of the Austrian HCl and Usability Engineering Grou, November, p. 101-123.

135 Springer, Berlin, Heidelberg, 2010

VERHOEVEN, F.; VAN GEMERT-PIJNEN, L.; HENDRIX, R. The Development of a web-based tool for compliance with safe work practices; A case study about methicillin-resistant staphylococcus aureus.

136 Proceedings - International Conference on eHealth, Telemedicine, and Social Medicine, eTELEMED 2009. Anais...2009

137 VINK, P.; KONINGSVELD, E. A.; MOLENBROEK, J. F. Positive outcomes of participatory ergonomics in terms of greater comfort and higher productivity. Applied ergonomics v. 7, n. 4, p. 537-546, 2006.

138 VIMARLUND, V. et al. Organizational effects of information and communication technology (ICT) in elderly homecare: A case study. Health Informatics Journal, v. 14, n. 3, p. 195-210, 2008.

WÄRNESTÅL, P.; SVEDBERG, P.; NYGREN, J. Co-constructing child personas for health-promoting services with vulnerable children. Proceedings of the SIGCHI Conference on Human Factors in Computing

139 Systems. Anais...2014

140 WASTELL, D.; WHITE, S. Making sense of complex electronic records: Socio-technical design in social care. Applied Ergonomics, v. 45, n. 2 Part A, p. 143-149, 2014.

WEIGHTMAN, A. P. H. et al. Engaging children in healthcare technology design: Developing rehabilitation technology for children with cerebral palsy. Journal of Engineering Design, v. 21, n. 5, p.

$141579-600,2010$

WENT, K. Safer prescribing in intensive care: designing a system to reduce errors. Proceedings of the HCl'07 Conference on People and Computers XXI. Anais...2007Disponível em:

142 <http://www.bcs.org/upload/pdf/ewic_hc07_dcpaper9.pdf\%5Cnhttp://www.bcs.org/server.php?show=ConWebDoc.13996>

143 WILLARD, S. et al. Development and testing of an online community care platform for frail older adults in the Netherlands: A user-centred design. BMC Geriatrics, v. 18, n. 1, p. 1-9, 2018. WILLIAMSON, S. S.; GORMAN, P. N.; JIMISON, H. B. A mobile/web app for long distance caregivers of older adults: functional requirements and design implications from a user centered design process. Annual Symposium proceedings. AMIA Symposium. Anais...2014Disponivel em:

144 <http://www.ncbi.nlm.nih.gov/pubmed/25954469\%0Ahttp://www.pubmedcentral.nih.gov/articlerender.fcgi?artid=PMC4419890>

WOODS, L. et al. Conceptual Design and Iterative Development of a mHealth App by Clinicians, Patients and heir Families... Health Informatics Conference, Sydney Australia, 2018. Studies in Health

145 Technology \& Informatics, v. 252, p. 170-175, 2018. 
146 BARRY, M. et al. mHealth for Maternal Mental Health: Everyday Wisdom in Ethical Design. Proceedings of the 2017 CHI Conference on Human Factors in Computing Systems.2017 147 BIEDIGER-FRIEDMAN, L. et al. A Focus Group Investigation. Am J Health Behav., v. 40, n. 4, p. 461-471, 2016.

148 BURCHERT, S. et al. User-centered app adaptation of a low-intensity e-mental health intervention for Syrian refugees. Frontiers in Psychiatry, v. $10, n$. JAN, p. 1-18, 2019. CALVILLO-ARBIZU, J. et al. User-centred design for developing e-Health system for renal patients at home (AppNephro). International Journal of Medical Informatics, v. 125, $\mathrm{n}$. February, 149 p. 47-54, 2019.

150 DITHMER, M. et al. "The Heart Game": Using Gamification as Part of a Telerehabilitation Program for Heart Patients. Games for Health Journal, v. 5, n. 1, p. 27-33, 2016. DOS SANTOS, M. M. T. et al. Personalizing health-related ICT interface and application. Proceedings of the 7th International Conference on Software Development and Technologies for 151 Enhancing Accessibility and Fighting Info-exclusion. 2017

DUVAL, J. S.; MÁRQUEZ SEGURA, E.; KURNIAWAN, S. Spokelt. Extended Abstracts of the 2018 CHI Conference on Human Factors in Computing Systems - CHI '18. 2018. Disponível em:

152 <http://dl.acm.org/citation.cfm?doid=3170427.3186494>

FERNANDES, F.; DUARTE, L.; CARRIÇO, L. DETACH: Authoring Digital Therapeutic Artefacts. 2013 7th International Conference on Pervasive Computing Technologies for Healthcare and

153 Workshops. 2013

154 GARZO, A. et al. Design and development of a gait training system for Parkinson's disease. PloS one, v. 13, n. 11, p. e0207136, 2018.

HAKOBYAN, L. et al. A longitudinal evaluation of the acceptability and impact of a diet diary app for older adults with age-related macular degeneration. Proceedings of the 18th

155 International Conference on Human-Computer Interaction with Mobile Devices and Services. Anais...2016

HARDY, A. et al. How Inclusive, User-Centered Design Research Can Improve Psychological Therapies for Psychosis: Development of SlowMo. JMIR Mental Health, v. 5, n. 4, p. e11222,

1562018.

HAYNES, S. C.; KIM, K. K. A mobile system for the improvement of heart failure management: Evaluation of a prototype. Annual Symposium proceedings. AMIA Symposium. 2017

157 Disponível em:<http://www.ncbi.nlm.nih.gov/pubmed/29854150\%0Ahttp://www.pubmedcentral.nih.gov/articlerender.fcgi?artid=PMC5977691> HERSCHMAN, J. et al. Development of a smartphone app for adolescents with lupus: a collaborative meeting-based methodology inclusive of a wide range of stakeholders. Pan American

158 journal of public health, v. 35, n. 5-6, p. 471-6, 2014.

HOBSON, E. V. et al. The TiM system: developing a novel telehealth service to improve access to specialist care in motor neurone disease using user-centered design. Amyotrophic

159 Lateral Sclerosis and Frontotemporal Degeneration, v. 19, n. 5-6, p. 351-361, 2018.

160 HOLM, K. G. et al. Participatory design methods for the development of a clinical telehealth service for neonatal homecare. SAGE Open Medicine, v. 5, p. 1-8, 2017. HUBERTY, J. et al. Development and design of an intervention to improve physical activity in pregnant women using Text4baby. Translational Behavioral Medicine, v. 6, n. 2, p. 285-294, 1612016.

162 ENSEN, C. M. et al. Bridging the gap: A user-driven study on new ways to support self-care and empowerment for patients with hip fracture. SAGE Open Medicine, v. 6, p. 1-13, 2018. JURIC, S.; ZALIK, B. An innovative approach to near-infrared spectroscopy using a standard mobile device and its clinical application in the real-time visualization of peripheral veins. BMC 163 Medical Informatics and Decision Making, v. 14, n. 1, p. 1-10, 2014.

KATUSIIME, J.; PINKWART, N. Supporting Maternal Health Education in Developing Countries Using Mobile Phones-Results of a Pilot Study. Proceedings of the First African Conference on 164 Human Computer Interaction. 2016

KLAKEGG, S. et al. Informing Caregivers Through an Assistive Tool: An Investigation of Elderly Care Metrics. Proceedings of the 31st British Computer Society Human Computer Interaction 165 Conference. 2017

66 LAZAR, J. et al. Co-Design Process of a Smart Phone App to Help People With Down Syndrome Manage Their Nutritional Habits. Journal of Usability Studies, v. 13, n. 2, p. 73-93, 2018.

LEE, D. et al. Puzzle Walk: A Gamified Mobile App to Increase Physical Activity in Adults with Autism Spectrum Disorder. 10th International Conference on Virtual Worlds and Games for 167 Serious Applications (VS-Games). 2018

LI, X. et al. Serenity: A Low-Cost and Patient-Guided Mobile Virtual Reality Intervention for Cancer Coping. Proceedings - 2016 IEEE International Conference on Healthcare Informatics,

168 ICHI 2016. Anais...IEEE, 2016

LIN, F. S. et al. Graphical Tools for Doctor-Patient Communication: An App Prototype Design in Children's Pain Management. International Conference on Human-Computer Interaction.

1692016

LIN, W-J.;CHIU,M-C. Design a Personalized Brain-Computer Interface of LegoRobot Assisted by Data Analysis Method. Transdisciplinary Engineering: A Paradigm Shift: Proceedings of the

170 24th ISPE Inc. International Conference on Transdisciplinary Engineering, July 10-14, 2017. Vol. 5. IOS Press, 2017.

LIU, Y.-C. et al. Evaluating Mobile Health Apps for Customized Dietary Recording for Young Adults and Seniors: Randomized Controlled Trial. JMIR mHealth and uHealth, v. 7, n. 2, p. 1-15,

1712019.

LOPEZ, K. N. et al. Improving transitions of care for young adults with congenital heart disease: Mobile app development using formative research. Journal of Medical Internet Research,

172 v. 20, n. 9, p. 1-12, 2018.

173 LÖW, C. et al. ZENse - Supporting Everyday Emotional Reflection. 15th Human-Computer Interaction (INTERACT). Anais...2015

MADRIGAL-CADAVID, J. et al. Design and development of a mobile app of drug information for people with visual impairment. Research in Social and Administrative Pharmacy, p. 2-6,

1742019.

MAHER, M. et al. User-Centered Design Groups to Engage Patients and Caregivers with a Personalized Health Information Technology Tool. Biology of Blood and Marrow Transplantation,

175 v. 22, n. 2, p. 349-358, 2016.

MARIEN, S. et al. A User-Centered design and usability testing of a web-based medication reconciliation application integrated in an eHealth network. International Journal of Medical

176 Informatics, v. 126, p. 138-146, 2019. MELNICK, E. R. et al. Patient-Centered Decision Support: Formative Usability Evaluation of Integrated Clinical Decision Support With a Patient Decision Aid for Minor Head Injury in the

177 Emergency Department. Journal of Medical Internet Research, v. 19, n. 5, p. 1-12, 2017. MINGE, M. et al. Developing a Mobile System for Children and Teenagers with Scoliosis to Improve Therapy Adherence. Extended Abstracts of the $2018 \mathrm{CHI}$ Conference on Human Factors 178 in Computing Systems.2018 MONTEIRO-GUERRA, F. et al. The Design of a Mobile App for Promotion of Physical Activity and Self-Management in Prostate Cancer Survivors: Personas, Feature Ideation and Low-

179 Fidelity Prototyping. Proceedings - IEEE Symposium on Computer-Based Medical Systems. Anais...2017

MUMMAH, S. A. et al. Iterative development of Vegethon: A theory-based mobile app intervention to increase vegetable consumption. International Journal of Behavioral Nutrition and 180 Physical Activity, v. 13, n. 1, p. 1-12, 2016. 
181 NARVÁEZ, S. et al. Human-centered design of an mhealth app for the prevention of burnout syndrome. Studies in Health Technology and Informatics, v. 228 , n. 4, p. $215-219,2017$. NEUHAUSER, L. et al. Using design science and artificial intelligence to improve health communication: ChronologyMD case example. Patient Education and Counseling, v. 92, n. 2, p.

182 211-217, 2013.

PETERS, D. et al. Young people's preferences for an asthma self-management app highlight psychological needs: A participatory study. Journal of Medical Internet Research, v. 19, $n .4$, p. 183 1-13, 2017.

SANAUL HAQUE, M.; JÄMSÄ, T.; KANGAS, M. A theory-driven system model to promote physical activity in the working environment with a persuasive and gamified application. CEUR

184 Workshop Proceedings. Anais...2017

SCANDURRA, I.; HÄGGLUND, M.; KOCH, S. Integrated Care Plan and Documentation on Handheld Devices in Mobile Home Care. International Conference on Mobile Human-Computer

185 Interaction. Anais...2010 SERRANO, J. A. et al. Patients Initiated Timeline Marking of Events in Parkinson's Disease: Visualization of Time Correlation between Patients Marked Events and Acquired Data from

186 Sensors. International Conference on Augmented Cognition. 2014 Disponivel em: <http://link.springer.com/10.1007/978-3-319-07527-3>

187 SHALAN, A. et al. YORwalK: Desiging a smartphone exercise application for people with intermittent claudication. Studies in Health Technology and Informatics, v. 247, p. 311-315, 2018. SHELLMER, D. A. et al. Development and field testing of Teen Pocket PATH ${ }^{\circledast}$, a mobile health application to improve medication adherence in adolescent solid organ recipients Diana.

188 Pediatric transplantation, v. 20, n. 1, p. 130-140, 2016.

SOBRINHO, A. et al. Design and evaluation of a mobile application to assist the self-monitoring of the chronic kidney disease in developing countries. BMC Medical Informatics and

189 Decision Making, v. 18, n. 1, p. 1-14, 2018.

SVARRE, T.; LUNN, T. B. K.; HELLE, T. Transforming paper-based assessment forms to a digital format: Exemplified by the Housing Enabler prototype app. Scandinavian Journal of

190 Occupational Therapy, v. 24, n. 6, p. 438-447, 2017.

THOMSON, J. et al. Aspira: Employing a serious game in an mHealth app to improve asthma outcomes BT - 5th IEEE International Conference on Serious Games and Applications for Health, SeGAH 2017, April 2, 2017 - April 4, 2017. BT - 5th IEEE International Conference on Serious Games and Applications for Health.2017Disponivel em:

$191<$ <ttp://dx.doi.org/10.1109/SeGAH.2017.7939268>

WOODS, L. et al. Conceptual Design and Iterative Development of a mHealth App by Clinicians, Patients and heir Families... Health Informatics Conference, Sydney Australia, 2018. Studies

192 in Health Technology \& Informatics, v. 252, p. 170-175, 2018.

ATKINSON, N. L. et al. User-centered research on breast cancer patient needs and preferences of an internet-based clinical trial matching system. Journal of Medical Internet Research, 193 v. 9, n. 2, p. 1-11, 2007.

ATKINSON, N. L. et al. Rural eHealth nutrition education for limited-income families: an iterative and user-centered design approach. Journal of medical Internet research, v. 11, n. 2, p.

$1941-13,2009$.

195 BRADFORD, D. et al. Interacting with genomic data: Clinician requirements and prototype structure. Studies in Health Technology and Informatics, v. 239 , p. 1-7, 2017.

196 ELF, M. et al. Young carers as co-designers of a web-based support system - The views of two publics. Informatics for Health and Social Care, v. 37, n. 4, p. 203-216, 2012. FISHER, A. M. et al. User-centered design and usability testing of RxMAGIC: a prescription management and general inventory control system for free clinic dispensaries. BMC Health

197 Services Research, v. 18, n. 1, p. 1-12, 2018.

FONDA, S. J. et al. Combining iGoogle and personal health records to create a prototype personal health application for diabetes self-management. Telemedicine and e-Health, $v$. $16, \mathrm{n}$. 198 4, p. 480-489, 2010.

199 GONCALVES, S. et al. Integration of all information sources in a clinical environment. Health Informatics Journal, v. 5, n. 4, p. 193-199, 1999.

$\mathrm{HE}$, X. et al. Prototyping an Interactive Visualization of Dietary Supplement Knowledge Graph. Proceedings - 2018 IEEE International Conference on Bioinformatics and Biomedicine,

200 BIBM 2018. Anais...IEEE, 2019

201 JENKINSON, J. et al. Development and evaluation of sentinel node biopsy: a continuing professional development course. Journal of Biocommunication, v. $29, \mathrm{n}$. 4, p. 5-10, 2003.

JONES, R. B. et al. A web-based psychoeducational intervention for adolescent depression: design and development of MoodHwb. Journal of Medical Internet Research, v. 20, n. 2, p.

202 1-19, 2018.

203 KILLEEN, O. et al. User-Centered Design of the eyeGuide, a Tailored Glaucoma Behavior Change Program Olivia. Journal of glaucoma, v. 25, n. 10, p. 815-821, 2016. 


\section{APPENDIX B}

\begin{tabular}{|c|c|}
\hline Method & Papers ID \\
\hline Prototype & $\begin{array}{l}2-5,7-38,40-63,65,66,69-91,93-103,105,106,108-123,126-132,134 \\
-203\end{array}$ \\
\hline Observation & $\begin{array}{l}5,12,16,20,26,27,36,38,42,43,45,49,51,52,54,56,58,59,66,72,73,77,79 \\
81,95,96,98,99,107-110,112-114,118,123-128,130,138,143,150,154 \\
160,163,166-168,176-178,182,184,190,199\end{array}$ \\
\hline Interview & $\begin{array}{l}1-5,7,8,11-13,16-22,25,27-30,32-37,41,43-48,50-59,61-63,65 \\
67-74,76,79-83,85,87-89,92,94,95,97-103,105,108-110,112-114, \\
116,118,119,124,126,128,129,131-134,136,137,139,140,143-145,147- \\
162,164,165,168-170,172-174,176-182,184,187-191,193-200,202,203\end{array}$ \\
\hline Cenarios & $23,27,30-33,45,47,57,63,66,69,117,120,126,153$ \\
\hline Brainstorming & $37,45,67,68,158,167,179,180$ \\
\hline Questionnaire & $\begin{array}{l}1,3-6,10,11,14,24-26,32,39,41,43,45-47,51,54,57,60,64,66,67,70 \\
72,78-81,83,85,88,91,97,101,103,111,114,117,120,121,125,128,138 \\
145,149,152,154,156,163,168-171,174-176,180,181,183,197,199,201\end{array}$ \\
\hline Focus group & $\begin{array}{l}11,17,21,23,24,28,29,31,37,42,52,54,55,57,59,61,65,71,74,79,80,91, \\
100,102,106,113,114,117-119,121,122,124,127,129-131,133,134,139, \\
142,145,147,148,150,160,166,176,177,180,182,186,193,194,196,198,200 \\
202\end{array}$ \\
\hline User stories & $27,47,158,197$ \\
\hline Persona & $15,27,37,44,104,106,122,139-141,154,159,179,191$ \\
\hline Usability test & $\begin{array}{l}20,32,42,44,51,59,60,62,65,110,114,123,127,128,133,148,182,186,188- \\
190,194,197,200\end{array}$ \\
\hline User cases & $46,104,154,197$ \\
\hline Heuristic evaluation & $28,44,110,117,133,135,142,191$ \\
\hline Contextual inquiry & $42,56,62,182$ \\
\hline Journey map & $106,141,159$ \\
\hline Cognitive walkthrough & $28,51,57,114,126,142$ \\
\hline Workshop & $\begin{array}{l}9,18,23,58,68,71,87,103,106,107,123,126,139-141,150,158-160,162 \\
166,178,183,185,190,192,195,202\end{array}$ \\
\hline Survey & $\begin{array}{l}17,64,77,84,93-95,103,106,125,136,138,151,161,167,172,180,182,186 \text {, } \\
187\end{array}$ \\
\hline Talk aloud / think aloud & $\begin{array}{l}11,32,51,60,62,65,72,75,76,79,86,90,95,96,101,102,105,108,110,126- \\
128,134,135,145,148,154,165,168,181,197,200\end{array}$ \\
\hline Task analysis & $4,61,63,70,129$ \\
\hline Simulation & $26,58,160,197$ \\
\hline Storytelling & 139 \\
\hline Card sorting & $19,44,76,89,90,135,136,190$ \\
\hline Storyboard & $18,23,81,119,126,139,140,166,169,178,192$ \\
\hline Sketches & $18,123,192$ \\
\hline
\end{tabular}

